\title{
НОРМАТИВНО-ПРАВОВІ ЗАСАДИ ЗАБЕЗПЕЧЕННЯ ЯКОСТІ ЗАГАЛЬНОЇ СЕРЕДНЬОЇ ОСВІТИ
}

В статті розглядаються питання нормативно-правового забезпечення якості загальної середньої освіти. Проаналізовано діяльність закладу освіти з точки зору правового аспекту. Визначено, що нормативно-правове забезпечення це засоби, способи і прийоми, що забезпечують як підвищення якості освіти, інновацій, ефективності та стабільності освітніх процесів, а також реалізацію намічених проектів, планів і визначення шляхів вдосконалення особистості в освітньому процесі. Виявлено, що нормативно-правове регулювання сфрери загальної середньої освіти в Україні є сукупністю правових засобів, за допомогою яких здійснюється правове регулювання суспільних відносин в сфрері освіти. Формування з урахуванням європейських стандартів і міжнародного досвіду прогресивної нормативно-правової бази, в першу чергу, щодо забезпечення якості освіти є перш за все одним з основних чинників, що забезпечують реалізацію прав людини на якісну освіту. Зазначено, що до керівних органів та установ, які здійснюють в межах повноважень, забезпечення якості освіти в сфері загальної середньої освіти, відносяться центральний орган виконавчої влади із забезпечення якості освіти та його спеціально уповноважені територіальні органи, які проводять зовнішнє незалежне оцінювання своїх регіональних відділень, місцевих державних адміністрацій та органів місцевого самоврядування, акредитованих профессійних об'єднань, інших акредитованих юридичних осіб, які здійснюють незалежну оцінку якості освіти та освітньої діяльності закладів освіти. Автором наголошено, що Україні сорормована достатня правова база яка скерована на виконання стратегічних завдань в системі якості освіти відповідних для демократичного суспільства.

Ключові слова: загальна середня освіта, нормативно-правові акти, засади забезпечення якості загальної середньої освіти.

Постановка проблеми. У період реформування системи освіти в Україні актуальним $€$ питання щодо оптимізації діяльності загальної середньої освіти. Одним з пріоритетних напрямків реалізації принципів сучасної освітньої політики є вдосконалення нормативно-правового регулювання сфери освіти та освітньої діяльності. На сьогоднішній день нормативно-правове забезпечення якості загальної середньої освіти та його відповідність законодавству на різних рівнях $є$ об'єктом підвищеної уваги у ссрері управління освітою з боку державних органів контролю та нагляду, керівників, учасників освітньої діяльності та громадськості.

У зв'язку з процесами, які відбуваються в суспільстві виникає необхідність в поліпшенні нормативно-правової бази системи загальної середньої освіти.

Аналіз останніх досліджень та публікацій Дослідженням державного управління загальної середньої освіти займались такі вчені та дослідники, як В. Кременець, В. Луговий, Т. Лукіна, В. Лунячек, Н. Мельтюхова, Н. Нижник, В. Огнев'юк, Г. Одінцова, І. Семенець-Орлова та ін.

Мета статті визначити сутність та зміст нормативно-правового забезпечення якості загальної середньої освіти.

Виклад основного матеріалу. Нормативно-правове забезпечення це засоби, способи і прийоми, які забезпечують підвищення якості освіти, ефективність та стабільність освітніх процесів, а також реалізацію запланованих проєктів і визначення шляхів вдосконалення особистості в освітньому процесі. Потреба у вдосконаленні нормативно-правової бази в системі загальної середньої освіти визначено радикальними змінами, які пов'язані з соціально-економічними, політичними та освітньо-прогностичними умовами в Україні. 
Варто наголосити, що нормативно-правове регулювання сфери загальної середньої освіти в Україні - це сукупність правових засобів, за допомогою яких здійснюється правове регулювання суспільних відносин в сфері освіти. Правові норми, які здійснюють регулювання суспільних відносин формують систему з характерною для неї ієрархією рівнів, зв'язків і структури. Формування з урахуванням європейських стандартів і міжнародного досвіду прогресивної нормативно-правової бази, в першу чергу, щодо забезпечення якості освіти є перш за все одним з основних чинників, що забезпечують реалізацію прав людини на якісну освіту [1].

На думку Ю. Битяка нормативно-правове регулювання - це один з головних інструментів реалізації державної політики (як на регіональному, так і на державному рівні). Сфера державної політики в Україні традиційно охоплює систему цілей і пріоритетів розвитку країни, соціальної сфрери, економіки, суспільства, сорормованою державною владою [1].

Україна закріпила суспільну і державну значущість загальної середньої освіти та освіти в цілому за допомогою прийняття відповідних статей Конституції [2], а також Законів України “Про освіту” [3], “Про внесення змін до законодавчих актів з питань загальної середньої та дошкільної освіти щодо організації навчально-виховного процесу", “Про повну загальну середню освіту" [4], та інших актів законодавства у сорері освіти і науки, міжнародних договорів України утворюють систему освітнього законодавства нормативно-правових документів.

За дотриманням законодавства у сфері освіти спостерігають управлінці, які виконують відповідні заходи контролю. В першу чергу, вони перевіряють вміст нормативно-правової бази, а потім як вона реалізується.

Основними завданнями законодавства України про загальну середню освіту є:

- управління суспільними відносинами, що виникають у процесі реалізації права людини на повну загальну середню освіту;

- забезпечення права людини на доступність та безоплатність здобуття повної загальної середньої освіти;

- забезпечення необхідних умов для функціонування та розвитку системи загальної середньої освіти;

- зобов'язання громадян України на здобуття повної загальної середньої освіти;
- якість повної загальної середньої освіти та якість освітньої діяльності;

- визначення структури та змісту повної загальної середньої освіти;

- визначення органів управління у галузі загальної середньої освіти та їх повноважень;

- визначення прав та обов'язків учасників освітнього процесу;

- встановлення відповідальності за порушення законодавства України про загальну середню освіту [4].

Отже, кожному громадянину забезпечується доступність та якість повної загальної середньої освіти. Державні органи управління і установи, що здійснюють контроль якості освіти в сфрері загальної середньої освіти, включають центральний орган виконавчої влади із забезпечення якості освіти та його спеціально уповноважені територіальні органи, які проводять зовнішнє незалежне оцінювання своїх регіональних відділень, місцеві державні адміністрації,а також органи місцевого самоврядування, акредитовані профресійні організації, інші акредитовані юридичні особи, які проводять незалежну оцінку якості освіти та освітньої діяльності освітніх установ.

Центральним галузевим органом виконавчої влади, відповідальним за розробку та реалізацію державної політики в системі загальної середньої освіти $€$ Міністерство освіти і науки України (далі - МОН). Його повноваження та фрункції полягають в участі у визначенні державної політики в галузі освіти, науки, професійної підготовки, розробці програми розвитку освіти та державних стандартів освіти. Також $\mathrm{MOH}$ встановлює державні стандарти знань з кожного предмета, визначає мінімальні нормативи матеріально-технічного, фрінансового забезпечення навчальних закладів, здійснює навчально-методичне керівництво, контроль за дотриманням державних стандартів освіти, державне інспектування. Окрім вищезазначених функцій міністерство забезпечує зв'язок із закладами освіти, державними органами інших країн з питань, які входять до його компетенції, розробляє умови прийому до навчальних закладів, забезпечує випуск підручників, посібників, методичної літератури, розробляє проєкти положень про навчальні заклади, що затверджуються Кабінетом Міністрів України, організовує атестацію педагогічних і науково-педагогічних працівників щодо присвоєння їм кваліфікаційних категорій, педагогічних та вчених звань, здійснює 
керівництво державними навчальними закладами, тощо [5, с. 53-54].

Варто відмітити, що в Україні здійсню $є$ контроль за дотриманням відповідності рівня якості у сорері загальної середньої освіти Незалежний центр оцінювання якості освіти. Це державна установа, яка здійснює зовнішнє незалежне оцінювання результатів навчання, здобутих на певному освітньому рівні, а також проводить моніторингові дослідження якості освіти.

Забезпеченню якості повної загальної освіти присвячено Розділ VI Закону України “Про повну загальну середню освіту”. Законом передбачено компоненти та систему забезпечення якості загальної середньої освіти, яка включає:

- внутрішню систему забезпечення якості освіти (в закладах освіти);

- систему зовнішнього забезпечення якості освіти;

- систему забезпечення якості в діяльності органів управління та установ, що здійснюють зовнішнє забезпечення якості освіти [4].

Законом України “Про освіту”, також, передбачена подібна система забезпечення якості освіти, проте на відміну від попереднього закону, сучасний нормативно-правовий акт розширив перелік процедур та заходів, що проводяться для забезпечення системи якості освітньої діяльності, зокрема загальної середньої освіти.

Отже, якісна загальна середня освіта відповідає за процес засвоєння учнями необхідних знань, навичок і умінь, формування поглядів та світогляду для інтелектуального, фрізичного й соціального розвитку особистості для гідного існування в сучасному світі. Формування загальноприйнятих цінностей заснована на принципах гуманізму, взаємоповаги в інтересах сім'ї, суспільства і держави.

Також варто відмітити, що провідну роль у системі якості освіти в Україні покладено на професійно підготовлених кадрів. До педагогічної діяльності долучаються особи знання, уміння і навички яких відповідають критеріям державних стандартів та мають відповідну освіту та професійну підготовку у необхідній сфері. Діючим законодавством України, положенням та статутами відповідних закладів освіти визначаються професійні права й обов'язки педагогічних працівників під час їх виконання [7]. Окрім того, законодавець визначає період навчання, загальну організацію навчального процесу, права та обов'язки кожного з учасників освітнього процесу.
Варто наголосити, що якісна загальна середня освіта, зокрема, повинна відповідати вимогам державного стандарту, яким визначено компоненти і зміст освіти, встановлює державні вимоги до випускників.

Проведений аналіз дає підстави сказати, що в Україні за роки незалежності були сформовані нормативно-правові засади які сприяли розвитку та якості системи загальної середньої освіти, серед яких конституційне визначення права громадян брати участь в управлінні державними справами; у законодавчих, підзаконних актах та інших нормативно-правових документах закріплено основні права що належать освітнім спільнотам на самоврядування, сформовано нормативні засади діяльності інших колегіальних та одноособових органах освіти, нормативно закріплено права широкого кола громадськості на співпрацю та контроль за діяльністю органів влади щодо якості освітнього процесу.

Однак дослідження реального стану нормативної бази системи якістю загальної середньої освіти свідчить про необхідність більш детального вдосконалення її відповідно до сучасних вимог. Насамперед необхідною умовою $є$ створення системи освіти, яка була б конкурентоспроможною до подібних закладів освіти ЄС, підтримувала та використовувала найкращі практики, як європейські, так і світові, з урахуванням сучасного розвитку українського суспільства, національних традицій та методів. Освіта $€$ продуктом на ринку світових освітніх послуг. Тому, необхідно значно розширити вплив закладів освіти на створення людських ресурсів у всіх сферах соціальної діяльності, щоб створити широке коло висококваліфікованих кадрів, які відповідали б сучасним вимогам світового ринку праці.

Висновки та пропозиції. Аналізуючи нормативно-правові акти управління якістю в загальній середній освіті, можна зробити висновок, що в Україні сформована достатня правова база яка скерована на виконання стратегічних завдань в системі якості освіти відповідних для демократичного суспільства. Ця основа охоплює сфери освіти з прав людини, громадянську освіту, міжкультурну освіту та вивчення світових проблем.

Однак на шляху реформування освітнього процесу для задоволення сучасних потреб залишається ще багато питань, які потребують експертної уваги науковців, дослідників, та управлінців. Серед цих питань можемо 
виділити: підготовка педагогічних працівників відповідно сучасним вимогам, забезпечення якості культурної та політичної освіти для демократичного громадянства та освіти з прав людини, фрормування іміджевої системи загальної середньої освіти, постійний моніторинг системи громадянської освіти та ін.

\section{Список використаної літератури:}

1. Битяк Ю. Адміністративне право України. Київ, 2005. 544 c.

2. Конституція України URL: https:// zakon.rada.gov.ua/laws/show/254\%D0\%BA/96\%D0\%B2\%D1\%80\#Text.

3. Закон України “Про освіту". URL: https:// zakon.rada.gov.ua/laws/show/2145-19\#Text.

4. Закон України "Про повну загальну середню освіту". URL: https://zakon.rada.gov.ua/laws/ show/848-19\#Text.

5. Бабельчук О. Система управління середньою освітою в сучасній українській державі. Запоріжжя: [б. в.], 2015 р. С. 51-57.
6. Паращенко Л. Державне управління розвитком загальної середньої освіти в Україні: методології, стратегії, механізми : [монографія]. Київ, 2011. 536 c.

7. Лукіна Т. Державне управління якістю загальної середньої освіти в Україні. Київ. 2005.

8. Закон України "Про ліцензування видів господарської діяльності" URL: https:// zakon.rada.gov.ua/laws/show/222-19\#Text.

9. Красняков $Є$. Державна політика в галузі освіти України в контексті реалізації освіти для демократичного громадянства і прав. URL: http:// www.viche.info/journal/2634/.

10.Жиляєв І. Особливості сучасного правового забезпечення модернізації освіти України. URL: http://www.viche.info/journal/1304/

11. Нормативно-правова база Міністерства освіти та науки України. URL: http://mon.gov.ua/ activity/education/zagalna-serednya/normativnopravova-baza1.html.

12. Семенець-Орлова I. Нормативно-правове забезпечення освітніх змін в Україні. Теорія та практика державного управління. № 3. 2017. С. 91-100.

\section{Hrabovenko N. V. Regulatory and legal principles of quality assurance of general secondary education}

The article considers the issues of regulatory and legal quality assurance of general secondary education. The activity of the educational institution is analyzed from the point of view of the legal aspect. It is determined that regulatory support is a means, methods and techniques that provide both improving the quality of education, innovation, efficiency and stability of educational processes, as well as the implementation of planned projects, plans and identifying ways to improve personality in the educational process.

It is revealed that the normative-legal regulation of the sphere of general secondary education in Ukraine is a set of legal means by means of which the legal regulation of public relations in the sphere of education is carried out. The formation of a progressive regulatory framework, taking into account European standards and international experience, primarily to ensure the quality of education is primarily one of the main factors ensuring the implementation of human rights to quality education.

It is noted that the governing bodies and institutions that carry out within the powers to ensure the quality of education in general secondary education include the central executive body for quality assurance of education and its specially authorized territorial bodies that conduct external independent evaluation of their regional offices, local state administrations and local governments, accredited professional associations, other accredited legal entities that carry out an independent assessment of the quality of education and educational activities of educational institutions.

The author emphasizes that Ukraine has a sufficient legal framework aimed at fulfilling strategic objectives in the quality of education system appropriate for a democratic society.

Key words: general secondary education, regulations, principles of quality assurance of general secondary education. 